\title{
Pseudotachylyte in the Monte Maggiore ophiolitic unit (Alpine Corsica): a possible lateral extension of the Cima di Gratera intermediate-depth Wadati-Benioff paleo-seismic zone
}

\author{
Olivier Fabbri ${ }^{1, *}$, Rémi Magott ${ }^{2}$, Marc Fournier ${ }^{3}$ and Lucas Etienne ${ }^{1}$ \\ ${ }^{1}$ UMR CNRS 6249 Chrono-environnement, Université Bourgogne Franche-Comté, Besançon, France \\ 2 UMR CNRS 7358 CRPG, rue Notre-Dame des Pauvres, Vandoeuvre-les-Nancy, France \\ ${ }^{3}$ Sorbonne Université, CNRS-INSU, Institut des Sciences de la Terre Paris, ISTEP UMR 7193, 75005 Paris, France
}

Received: 12 June 2018 / Accepted: 3 December 2018

\begin{abstract}
At the northern end of the Cap Corse peninsula, several klippes of ultramafic rocks (peridotite and serpentinite), among which the Monte Maggiore klippe is the least serpentinized one, rest upon continental-crust derived rocks (Centuri gneisses) and basic or metasedimentary schists (Schistes Lustrés). The Monte Maggiore ophiolitic klippe shares several characteristics with the Cima di Gratera klippe located $30 \mathrm{~km}$ further south. First, the two units are composed of a lherzolitic peridotite. Second, they record the same succession of metamorphic events. Third, in the Cap Corse tectonic pile, the two units occupy the highest structural position. Several differences are also observed. First, mafic rocks are significantly less abundant in the Monte Maggiore unit, where they are restricted to dykes cross-cutting the peridotite, than in the Cima di Gratera unit, where they constitute an entire sub-unit. Second, pyroxenite layers are more common at Monte Maggiore than at Cima di Gratera. Despite these differences, the Monte Maggiore and Cima di Gratera klippes can be considered as possible lateral equivalents of a single ophiolitic unit having covered the entire Cap Corse before subsequent erosion. Pseudotachylyte of seismic origin is newly discovered in the Monte Maggiore klippe. The host rock is a cataclastic serpentinized peridotite affected by a cataclastic foliation that is either flat-lying or steeply dipping. Pseudotachylyte fault veins are parallel to the host rock cataclastic foliation. The small lateral extension and the small thickness of fault veins along with frequent cross-cutting relationships suggest that the exposed pseudotachylyte most likely results from numerous small magnitude seismic events such as swarms or aftershocks rather than from large magnitude shocks. All these characteristics are also observed at the Cima di Gratera klippe where they are interpreted as the testimonies of a fossil intermediate-depth Wadati-Benioff zone at the time of subduction of the Ligurian Tethys oceanic lithosphere. Mineral assemblages that could constrain the depth of formation of the pseudotachylyte lack in the Monte Maggiore area. Despite this uncertainty, and given the similarities with the Cima di Gratera occurrences, the pseudotachylyte veins newly discovered at Monte Maggiore are tentatively related to the seismic activity linked with the subduction of the Piemonte-Ligurian oceanic lithosphere in Eocene times. This interpretation suggests that the fossil Wadati-Benioff zone could be traced further south in Alpine Corsica and further north in the Piemontese zone of the western Alps.
\end{abstract}

Keywords: pseudotachylyte / cataclasite / intermediate-depth seismicity / peridotite / Wadati-Benioff zone / Alpine Corsica

Résumé - Les pseudotachylytes de l'unité ophiolitique du Monte-Maggiore (Corse alpine): une possible extension latérale de la zone sismique de profondeur intermédiaire du plan de WadatiBenioff du Cima di Gratera. Dans la partie nord du Cap Corse, plusieurs klippes formées de roches ultramafiques (péridotites et serpentinites), parmi lesquelles la klippe du Monte Maggiore constituée de péridotites peu serpentinisées, reposent en contact anormal sur des roches d'affinité continentale (gneiss de Centuri) ou océaniques (Schistes Lustrés). La klippe du Monte Maggiore présente des similitudes avec celle du Cima di Gratera située $30 \mathrm{~km}$ plus au sud : en premier lieu, la péridotite constituant les deux unités est une lherzolite; puis, les deux unités ont enregistré la même succession d'événements métamorphiques; ensuite,

*Corresponding author: olivier.fabbri@univ-fcomte.fr 
dans l'empilement tectonique du Cap Corse, les deux unités occupent la position structurale la plus élevée. Des différences sont également observées : les gabbros sont rares au Monte Maggiore, où ils n'affleurent qu'à l'état de dykes, alors qu'ils constituent une écaille d'importance kilométrique au Cima di Gratera; inversement, les niveaux de pyroxénite sont abondants au Monte Maggiore et rares au Cima di Gratera. Malgré ces différences, les deux klippes du Monte Maggiore et du Cima di Gratera sont considérées comme faisant partie d'une même unité ophiolitique ayant recouvert le Cap Corse, avant d'être partiellement érodée. Des veines de pseudotachylyte d'origine sismique sont décrites pour la première fois dans la klippe du Monte Maggiore. L'encaissant des veines est une péridotite serpentinisée traversée par une foliation cataclastique qui est soit sub-horizontale, soit fortement pentée. Les veines de génération de pseudotachylyte sont parallèles à la foliation cataclastique de l'encaissant. La faible extension latérale, la faible épaisseur des veines de génération ainsi que les fréquentes relations de recoupement entre veines suggèrent que les pseudotachylytes soient vraisemblablement le résultat d'un grand nombre d'événements sismiques de petite magnitude, tels que des essaims ou des nuages de répliques d'événements plus importants. Les veines de pseudotachylytes de la klippe du Monte Maggiore présentent les mêmes caractéristiques que celles de la klippe du Cima di Gratera. Elles sont interprétées comme les reliques d'une zone sismique de profondeur intermédiaire (Wadati-Benioff) active lors de la subduction de la lithosphère océanique de la Téthys ligure à l'Eocène, même si les assemblages minéralogiques qui permettraient d'estimer la profondeur de formation des pseudotachylytes sont inexistants au Monte Maggiore à la différence du Cima di Gratera. En dépit de cette incertitude sur la profondeur de formation, les veines nouvellement découvertes au Monte Maggiore sont considérées comme des reliques de l'activité sismique associée à la subduction de l'océan liguro-piémontais à l'Eocène. Cette interprétation suggère que la zone de Wadati-Benioff de l'océan liguro-piémontais puisse être suivie vers le sud en Corse Alpine ou vers le nord le long de la zone piémontaise des Alpes occidentales.

Mot clés : pseudotachylyte / cataclasite / sismicité de profondeur intermédiaire / péridotite / zone de Wadati-Bénioff / Corse Alpine

\section{Introduction}

Subduction zone seismicity consists of shallow earthquakes (hypocenters shallower than $60 \mathrm{~km}$ ), intermediatedepth earthquakes (hypocenters between 60 and $300 \mathrm{~km}$ ), and deep-focus earthquakes (hypocenters deeper than $300 \mathrm{~km}$ ). Large magnitude $(>8)$ events of the first category typically nucleate and propagate between the subducting plate and the overriding plate. Their hypocenters therefore delineate the plate interface. Intermediate-depth and deep-focus earthquakes nucleate in the subducting slab, either in the crust or in the underlying mantle. Their hypocenters are aligned along what is classically referred to as the Wadati-Benioff seismic zone. In most subduction zones, precise hypocentral locations allow to further divide the Wadati-Benioff seismic zone into two subzones (Brudzinski et al., 2007). The separation between the two sub-zones is estimated between 8 and $30 \mathrm{~km}$, and appears to be a function of the age of the subducting plate. The upper sub-zone is located in the crust and/or in the uppermost part of the underlying mantle, while the lower sub-zone lies in the mantle (Igarashi et al., 2001; Preston et al., 2003; Kita et al., 2006; Abers et al., 2013; Nakajima et al., 2013).

Little is known about the exact mechanisms which control seismicity at intermediate depths. First, do intermediate-depth ruptures propagate along "standard" fault surfaces like in shallower depths or in volumes of several tens or hundreds of meters in thickness? Second, do these earthquakes reactivate already existing faults (for instance faults formed at the midoceanic ridge or at the trench outer wall in response to plate bending), or do they nucleate along newly formed faults [see contradictory views in Jiao et al. (2000) and Warren et al.
(2007)]? Third, what is the mechanism allowing intermediatedepth event to occur? Indeed, given the high confining pressures at such depths, potential faults should be stable, yet earthquakes occur. Two main mechanisms are currently under consideration to account for this paradox (Frohlich, 2006; Houston, 2015). The first mechanism is based on a fluid pressure increase at depth along potential fault surfaces, increase that could in turn bring faults to failure by reduction of the normal stress component acting on the faults. In this mechanism, dehydration reactions of hydrated minerals, typically serpentine, are frequently called for to account for the source of fluids (e.g., Peacock, 2001; Hacker et al., 2003). One example of such a mechanism frozen in the geological record is provided by Angiboust et al. (2012) in the Western Alps Monviso ophiolite. The second mechanism is referred to as thermal instability or as self-localizing (or spontaneous) thermal runaway (Braeck and Podladchikov, 2007; Kelemen and Hirth, 2007). The basic idea underlying this mechanism is that the shear strength of incipient ductile shear zones can drop suddenly, leading to shear heating and localized melting, hence resulting in a seismic rupture. Geological evidence for this mechanism should therefore require a close spatial association (that is, juxtaposition) of mylonite and pseudotachylyte along with evidence showing that the two types of rocks formed simultaneously. An example of such a spatial and temporal association in the geological record is provided by John et al. (2009). Besides, seismological data further suggest that the thermal runaway mechanism may account for the nucleation of intermediate-depth earthquakes in some subduction zones (Prieto et al., 2013). Conversely, Scambelluri et al. (2017) consider that the seismic ruptures frozen in the Western Alps 
(Lanzo Massif ophiolite were not caused by either of the two mechanisms mentioned above, but to "a release of differential stresses accumulated in strong dry metastable rocks". A similar interpretation was proposed by Menant et al. (2018) in their study of pseudotachylyte preserved in the Dent Blanche Valpelline continental unit. In other words, for these authors, an increase of the differential stress may allow a rupture, even if the normal stress is high. Albeit not conclusive, answers to these questions can also be looked for in the geological record, where evidence of intermediate-depth seismic ruptures can be preserved.

Pseudotachylyte veins exposed in the Cima di Gratera ophiolitic unit, Cap Corse peninsula (Alpine Corsica, France), are of seismic origin and a part of them was generated under blueschist to eclogite facies metamorphic conditions (Austrheim and Andersen, 2004; Andersen and Austrheim, 2006; Andersen et al., 2008, 2014; Deseta et al., 2014a, b, Magott et al., 2016, 2017). These veins were most likely formed in Late Cretaceous or Paleogene times during earthquakes in the Wadati-Benioff seismic zone of the Ligurian Tethys oceanic lithosphere subducting beneath a continent or an island arc.

The aim of this contribution is to report a new finding of pseudotachylyte from the northern end of the Cap Corse peninsula, in the Monte Maggiore ultramafic unit, and to discuss correlations between this occurrence and pseudotachylytes reported from the Cima di Gratera ophiolitic unit located $30 \mathrm{~km}$ south. These new findings suggest that the extension of the paleo-seismic Wadati-Benioff zone could be larger than initially thought (a few tens of kilometers instead of a few kilometers). They allow a discussion of the geodynamical significance of the Corsican pseudotachylytes within the general framework of the Alpine orogeny and the detailed setting of a Wadati-Benioff seismic zone of a subducting Tethysian oceanic lithosphere in Mesozoic to Cenozoic times.

\section{Geological setting of Alpine Corsica}

\subsection{Units}

Alpine Corsica is a segment of the Alpine orogen which is constituted by four domains (Mattauer and Proust, 1976; Durand-Delga, 1984; Vitale-Brovarone et al., 2011, 2013; Meresse et al., 2012): (1) the Corsican autochtonous foreland, of European affinity, comprising a Hercynian crystalline basement, a Permian volcano-sedimentary cover, and a reduced Mesozoic to middle Eocene sedimentary succession showing similarities with the Briançonnais series of the western Alps; (2) gneiss units derived from the stretched European continental margin and ocean-continent transition domain, (Lahondère, 1988; Vitale-Brovarone et al., 2011, Meresse et al., 2012, Lagabrielle et al., 2015); (3) the Schistes Lustrés domain including several thrust sheets made of ultramafic and mafic rocks originated from the Ligurian Tethys oceanic lithosphere and of metasedimentary rocks (marbles, meta-radiolarites, pelitic or calcareous schists) corresponding to metamorphosed oceanic deep-sea deposits; domains 2 and 3 are tectonically imbricated and are emplaced over the Corsican autochtonous foreland; (4) the Nappes Supérieures (upper nappes) overlie the other units and include ophiolitic thrust sheets and continent-derived crustal rocks with sedimentary rocks mostly of Cretaceous age. The first three domains experienced at least two stages of ductile deformation (Mattauer et al., 1981; Fournier et al., 1991; Jolivet et al., 1991) and were metamorphosed under omphacite blueschist to omphacite eclogite facies conditions (Ravna et al., 2010; Vitale-Brovarone et al., 2013). This high pressure/low temperature (HP-LT) metamorphism was followed by a retrograde greenschist facies metamorphism (Jolivet et al., 1990, 1991; Fournier et al., 1991). In domain (4), deformation remains brittle and the degree of metamorphism is weak (prehnite-pumpellyite assemblages in mafic rocks).

Ophiolitic thrust sheets of domain (3) are constituted by peridotite, serpentinite, gabbro and basalt and are regarded as lithospheric remnants of the Jurassic Ligurian Tethys (Piemonte-Ligurian) oceanic basin. Radiometric dating of the oceanic gabbros and plagiogranites yielded Middle to Late Jurassic ages between 181 and $152 \mathrm{Ma}$ (Beccaluva et al., 1981; Ohnenstetter et al., 1981; Rossi et al., 2002; Rampone et al., 2009; Li et al., 2015). The lack of dyke complex, the scarcity of magmatic rocks and the discontinuous distribution of gabbro bodies indicate that the spreading ridge of the PiemonteLigurian basin was of slow to very slow type (Lagabrielle and Lemoine, 1997; Piccardo, 2008).

\subsection{Models for the Alpine evolution}

The imbrication of continent-derived thrust sheets (domain 2) with ophiolitic units (domain 3) is classically interpreted as the result of an eastward-dipping Cretaceous to Paleogene subduction of the Piemonte-Ligurian oceanic basin and a part of the stretched European margin beneath the Apulia continental lithosphere followed by collision between Europe and Apulia in Eocene times (Mattauer and Proust, 1976; Mattauer et al., 1977, 1981; Warburton, 1986). Imbricated thrust sheets from domains (2) and (3) can be regarded as a suture between the two continental entities. The classical Alpine evolutionary model was further complicated by taking into account the Apennine orogeny (e.g., Durand-Delga and Rossi, 2002). The east-dipping Cretaceous subduction was followed in Paleocene to Eocene times by a west-dipping subduction of the oceanic lithosphere of a back-arc basin formed further east (Jolivet et al., 1998; Lacombe and Jolivet, 2005; Molli, 2008; Molli and Malavieille, 2010; Agard and Vitale-Brovarone, 2013; Vitale-Brovarone and Herwartz, 2013).

\section{Geology of the study area and regional correlation}

\subsection{The Monte Maggiore ophiolitic unit}

The study area is located in the northern end of the Cap Corse peninsula, around the Monte Maggiore (359 m). Geological maps and other studies (Jackson and Ohnenstetter, 1981; Malavieille, 1983; Lahondère, 1988; Harris, 1985; Lahondère and Lahondère, 1988, 1992; Jolivet et al., 1991; Daniel et al., 1996) indicate that Cape Corse is mostly composed of ophiolitic units (ultramafic and mafic rocks), oceanic-affinity meta-sedimentary deposits and meta-volcanics (schists, marbles, radiolarites, basaltic lavas and 


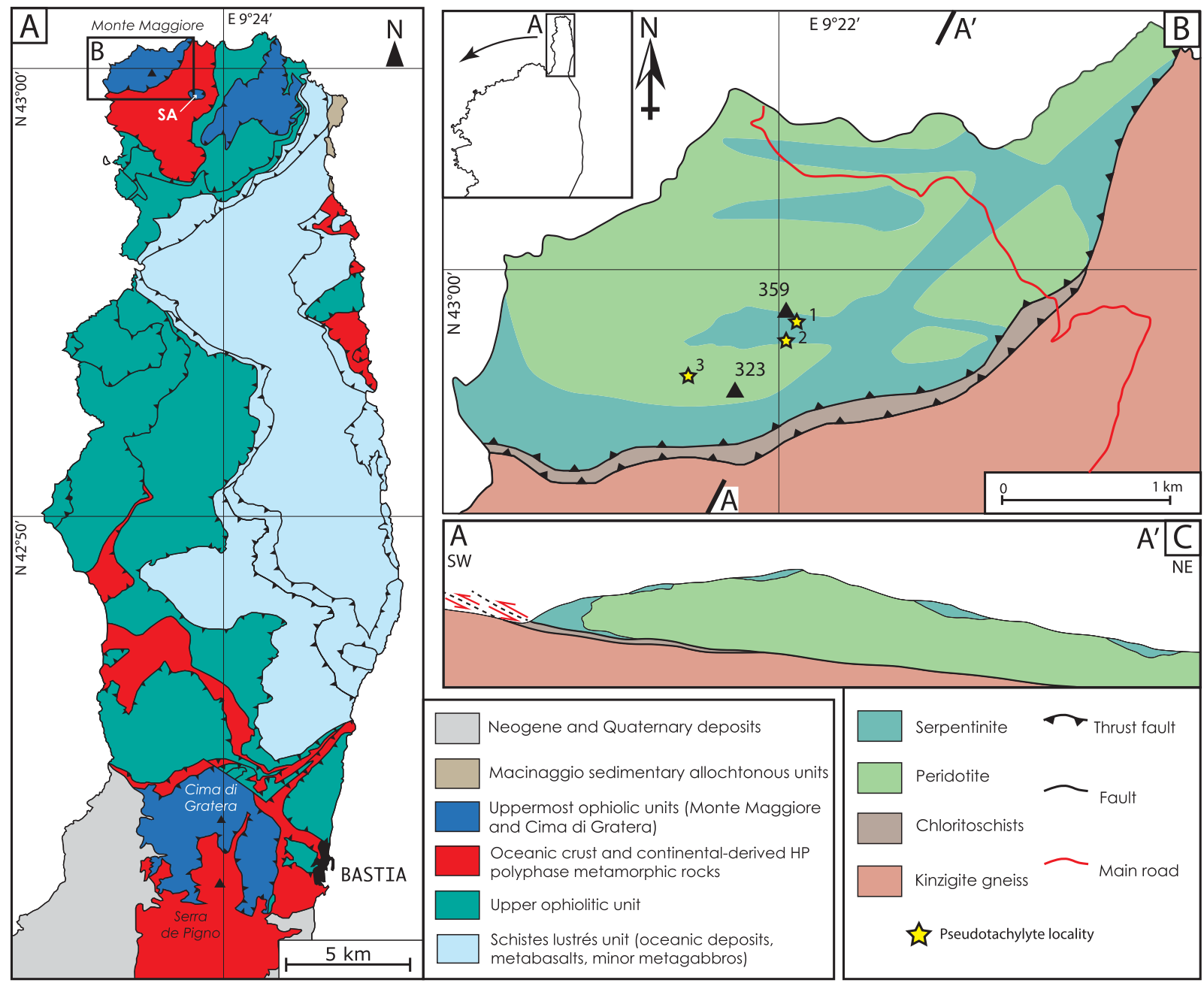

Fig. 1. A. Structural sketch map of Cape Corse peninsula showing the location of Monte Maggiore and Cima di Gratera ophiolitic units (modified after Lahondère and Lahondère 1988, 1992). SA is Sant'Antonino klippe. B. Geological sketch map of the Monte Maggiore klippe with pseudotachylyte localities. C. A-A' cross-section (see location on B).

breccias), and continent-derived orthogneiss and paragneiss units (Fig. 1).

The Monte Maggiore unit consists of a series of ophiolitic klippes (Lahondère and Lahondère, 1988; Jolivet et al., 1991; Lahondère, 1992), among which the westernmost one is referred to as the Monte Maggiore klippe (Fig. 1). These klippes, which are made of variously serpentinized peridotites with scarce gabbroic rocks, rest upon continental crust-derived gneisses or upon oceanic-affinity meta-basalts (also called prasinites) and meta-sedimentary rocks.

Intact (i.e., not serpentinized) peridotites are preserved in most of the Monte Maggiore klippe while, in the other klippes located further east, the peridotite is thoroughly serpentinized. The peridotite is a clinopyroxene-poor spinel lherzolite. The typical mineralogical composition consists of olivine, orthopyroxene, clinopyroxene, spinel and plagioclase (Jackson and Ohnenstetter, 1981; Rampone et al., 2008; Piccardo and Guarnieri, 2010). Planar layers of pyroxenite are locally observed in the Monte Maggiore klippe, as well as mafic rocks which are limited to small size dykes and pods of gabbros (troctolites to Fe-rich gabbros), Fe-rich diorites, dolerites and albitites sporadically intruded in the mantle rocks (Jackson and Ohnenstetter, 1981; Rampone et al., 2008; Piccardo and Guarnieri, 2010). These intrusive and extrusive rocks possess a MORB-type geochemical signature (Rampone et al., 2008; Piccardo and Guarnieri, 2010). Absolute datings of peridotite and gabbroic dykes with various methods provided Late Jurassic ages (181 to $155 \mathrm{Ma}$ ) for MORB melt percolation (Beccaluva et al., 1981; Ohnenstetter et al., 1981; Rampone et al., 2009; Piccardo and Guarnieri, 2010).

Jackson and Ohnenstetter (1981) report that the Monte Maggiore peridotite suffered from three metamorphic imprints (see also Ohnenstetter et al., 1976). An oldest greenschist to amphibolite facies condition event (1), likely Jurassic in age, is tentatively related to hydrothermal fluid flow at or near the mid-oceanic ridge. This early event is overprinted by a HP/LT event (2) which is attested, in plagioclase-bearing peridotite, by the presence of pure jadeite (Jackson and Ohnenstetter, 1981). In gabbroic intrusive rocks, Debret (2013) further describes mineral assemblages typical of blueschist facies conditions, namely jadeite, paragonite, zoisite and chlorite. This second event is tentatively related to the subduction, in 
Cretaceous to Paleogene times, of the Piemonte-Ligurian oceanic lithosphere. The youngest greenschist facies condition event (3), overprinting event (2), is possibly related to syn- to post-collision deformation, but its age is poorly constrained.

The Monte Maggiore peridotite shows a widespread foliation striking $\mathrm{N} 120$ to $\mathrm{N} 160^{\circ} \mathrm{E}$ and dipping moderately to strongly westward to southwestward. According to Jackson and Ohnenstetter (1981), the foliation is a mineral flattening surface which results from a high temperature $\left(>1100{ }^{\circ} \mathrm{C}\right)$ solid-state plastic flow. It bears a mineral and stretching lineation whose rake is close to zero.

Near the basal contact of the Monte Maggiore klippe, the peridotite is variably serpentinized, but the original granoblastic texture is still recognizable. Deformation consists in fractures which are locally abundant, with some scattered foliated shear zones whose thickness does not exceed a few meters. In the foliated shear zones, the foliation is deflected by shear surfaces. The S/C-like composite fabric indicates a component of reverse displacement. A thin band of very finegrained chlorite-epidote-rich ultramylonites separates the serpentinized peridotite from the underlying kinzigitic gneisses of the Centuri gneiss continental unit. The presence of epidote, chlorite and albite suggests that the chloritic schists are mylonitic serpentinites which suffered from fluid-assisted alteration during nappe emplacement.

\subsection{The Cima di Gratera ophiolitic klippe}

Unlike the Monte Maggiore unit, the Cima di Gratera ophiolitic unit, which lies as a klippe over continental crustderived rocks, is a tectonic superposition of two units: a lower ultramafic unit and an upper gabbro unit. The two units are separated by a composite brittle/ductile shear zone referred to as $\phi_{2}$ and which structural analysis can be found in Magott et al. (2017).

\subsubsection{The lower ultramafic unit}

The lower ultramafic unit consists of decameter to hectometer scale elliptical lenses of intact peridotite surrounded by moderately to strongly serpentinized peridotite. In the lowermost part, several slices of strongly foliated gabbro or of metasedimentary rocks are interpreted as the result of tectonic incorporation of the subjacent units during nappe emplacement. Metamorphic conditions during this tectonic incorporation were at least those of the greenschist facies. Higher conditions are suggested by bluish basic schist lenses, but the pervasive greenschist facies retrogression affecting the slices makes a detailed study difficult. Near the $\phi_{1}$ basal tectonic contact, the lower part of the unit consists of foliated serpentinites whose foliation is severely folded or sheared. This intense basal deformation, which is interpreted as a consequence of the emplacement of the nappe over its substratum, is more intense than the Monte Maggiore area. Serpentinite predominates in the lower part of the ultramafic unit and the degree of serpentinization decreases upwards from $\phi_{1}$ and towards $\phi_{2}$. Pyroxenite layers and gabbroic intrusions are significantly scarcer than in the Monte Maggiore area. The Cima di Gratera peridotite is lherzolitic in composition, and is constituted by olivine, diopside, enstatite and minor plagio- clase, Cr-spinel and magnetite (Deseta et al., 2014a, b). The geochemical characteristics of the Cima di Gratera rocks are much less known than their counterparts in the northern study area. The succession of the three metamorphic events (greenschist facies condition event $\rightarrow$ blueschist facies condition event $\rightarrow$ greenschist facies condition event) described in the Monte Maggiore area is also reported from the Cima di Gratera ultramafic unit (Deseta et al., 2014a, b; Magott et al., 2016, 2017).

\subsubsection{The upper mafic unit}

The mafic unit is predominantly composed of an equant metagabbro. Primary minerals are plagioclase, diopside, minor olivine and rare ilmenite. Alteration of plagioclase into sericite and of olivine into serpentine, iddingsite and magnetite is common. The texture often changes from, microgabbro to coarse-grained gabbro and to pegmatitic gabbro. Rare dolerite dykes cross-cut the gabbro. The basal part of the mafic unit consists of, a mylonitic metagabbro characterized by a conspicuous flat-lying to gently dipping foliation and a weakly marked lineation trending $\mathrm{N} 120^{\circ} \mathrm{E}$. The thickness of the mylonitic basal part is between $20 \mathrm{~cm}$ and $30 \mathrm{~m}$. As in the ultramafic unit, the succession of three metamorphic events (greenschist facies condition event 1 , blueschist facies condition event 2, greenschist facies condition event 3) described in the Monte Maggiore area is also recognized in the mafic unit (Deseta et al., 2014a, b; Magott et al., 2016, 2017).

\subsection{Correlation with the Cima di Gratera ophiolitic klippe}

The Monte Maggiore ophiolitic unit shares several characteristics with the Cima di Gratera unit. First, the two units are composed of a similar initial rock type, namely a lherzolitic peridotite. Second, the two units underwent the same succession of three metamorphic events. Third, in the Cap Corse tectonic stacking, the two units occupy the highest structural position (Lahondère and Lahondère, 1988, 1992; Lahondère, 1992).

Several differences are also observed. First, mafic rocks are significantly less abundant in the Monte Maggiore unit, where they are restricted to dykes cross-cutting the peridotite, than in the Cima di Gratera unit where they constitute an entire sub-unit (with rare dykes in the underlying ultramafic unit). The lack of mafic rocks in the Monte Maggiore unit can be explained in two ways. It can result from more advanced erosion in the north than in the south, or it can also be due to the sporadic occurrence of mafic plutons in slow-spreading ridges. Second, pyroxenite layers, common in the Monte Maggiore unit, are scarce in the Cima di Gratera unit.

Despite the differences, the Monte Maggiore unit and the Cima di Gratera unit can be considered as possible lateral equivalents of a single ophiolitic unit having covered the entire Cap Corse before being eroded except at the two ends of the peninsula. This tentative correlation between the two scattered units will be a working hypothesis for the rest of the paper. 

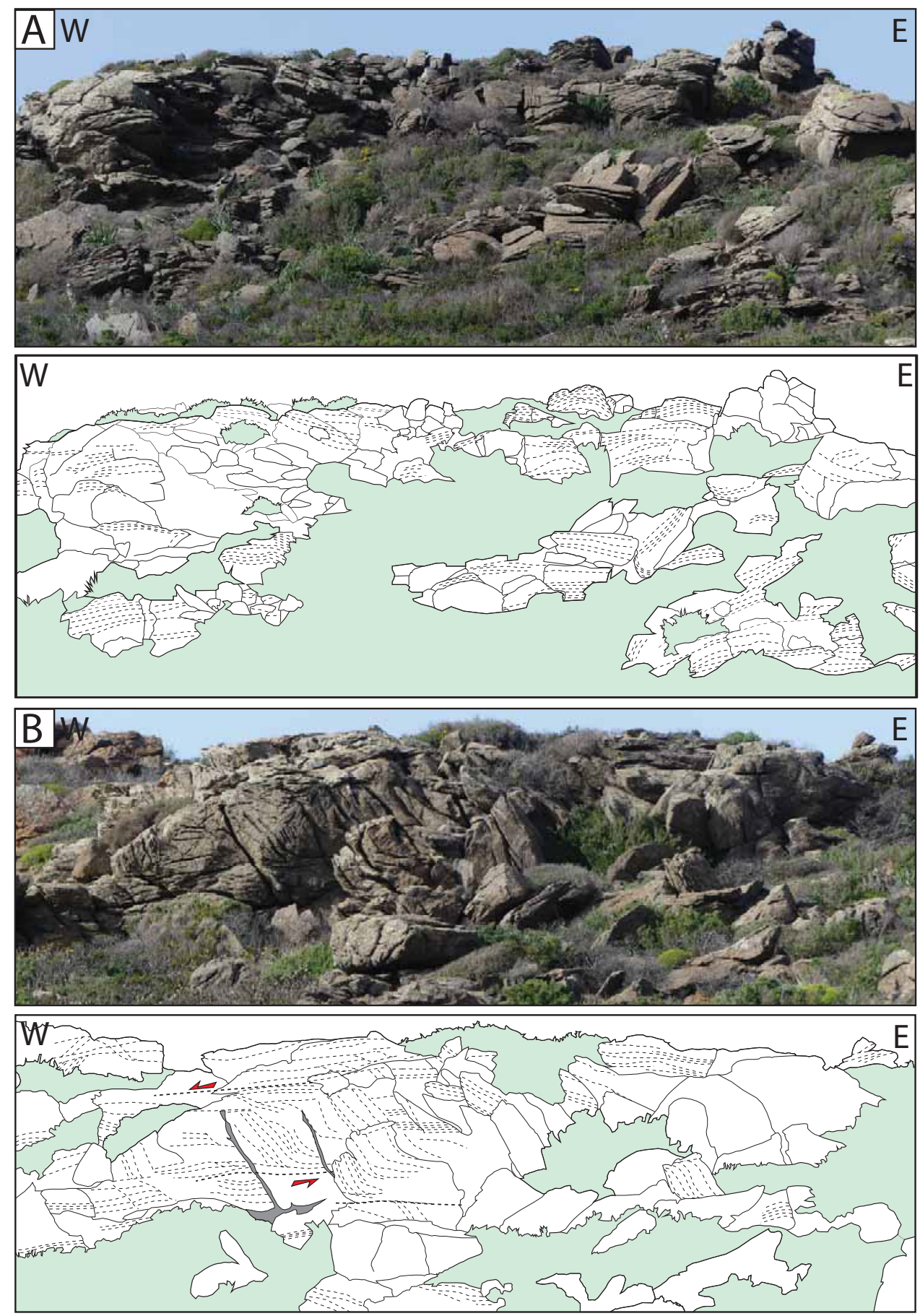

Fig. 2. Outcrop-scale views and line drawings of cataclastic foliations in the Monte Maggiore peridotite at localities 1 and 2. A. Flat-lying cataclastic foliation (locality 2). B. Steeply dipping cataclastic foliation deflected by the flat-lying cataclastic foliation (locality 1 ). Deflection indicates a top-to-the-W sense of shear.

\section{Pseudotachylyte and ultracataclasite in the Monte Maggiore klippe}

Peridotite-hosted pseudotachylyte veins in the Monte Maggiore klippe, initially reported by Magott (2016), are exposed at two localities close to the $359 \mathrm{~m}$ summit and, at a third locality close to another summit at $323 \mathrm{~m}$ (Fig. 1).

\subsection{Host peridotite cataclastic foliation}

In addition to being moderately to strongly serpentinized, the peridotite hosting pseudotachylyte and ultracataclasite veins is foliated (Fig. 2). The foliation is cataclastic and overprints the primary foliation described by Jackson and Ohnenstetter (1981). It is either flat-lying to gently dipping eastwards, or steeply dipping eastwards (Fig. 2). At locality 1, 

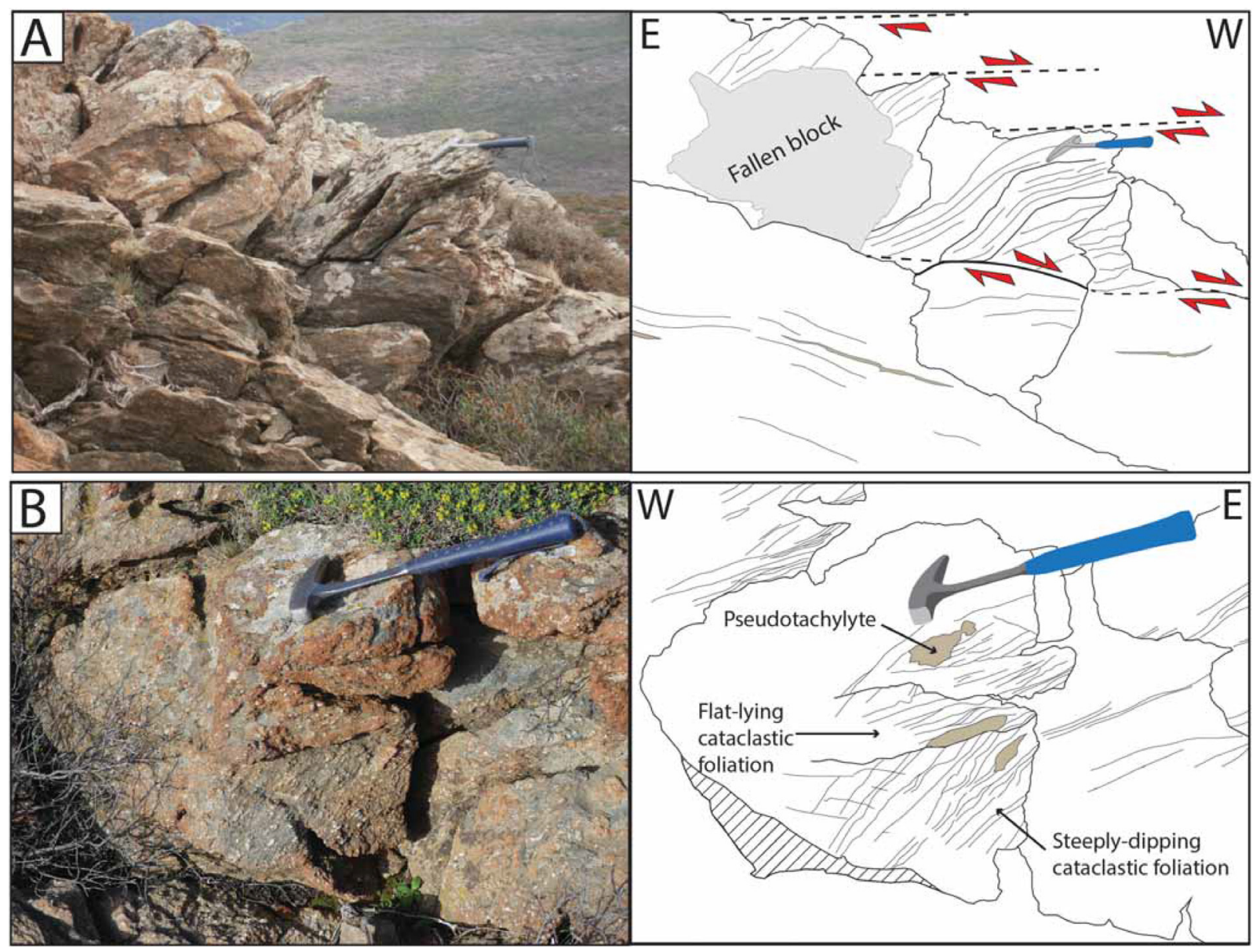

Fig. 3. Close views of the cataclastic foliations at locality 1. A. Steeply dipping cataclastic foliation deflected by the flat-lying cataclastic foliation. Deflection indicates a top-to-the-W sense of shear. B. Steeply dipping cataclastic foliation truncated by the flat-lying cataclastic foliation.

the flat-lying to gently dipping foliation crosscuts the steeply dipping one (Fig. 3), suggesting it is younger. The deflection of the steeply dipping foliation by the flat-lying one suggests a top-to-the-W sense of shear (Figs. 3A and 3B).

Thin sections show that the cataclastic foliation primarily consists in fractures crossing primary minerals of the peridotite, and along which serpentinization is developed. Offset minerals indicate that some of the fractures are actually faults. Deflection of a former foliation by a younger one suggests a top-to-the-E shear sense (Fig. 4), at variance with the top-to-the-W shear sense deduced from outcrop-scale deflections (Fig. 3).

\subsection{Pseudotachylyte veins}

Pseudotachylyte veins are distributed in the three outcrops, but their density increases upwards from the lowest parts of each exposure. A lot of minor faults truncate most veins. Despite this late brittle deformation, fault veins and injection veins can be identified (Fig. 5). Injection veins are rare and their length never exceeds $1 \mathrm{~cm}$. Fault vein thickness varies between 1 and $5 \mathrm{~mm}$. Their lateral extension cannot be estimated, due to exposure limitation or truncation by late faults. The largest visible extension is about $1 \mathrm{~m}$. Fault veins are either isolated or form imbricated networks. Based on their attitudes, fault veins can be sorted into two groups: steeply dipping veins and flat-lying to gently dipping veins (Fig. 6). Steeply dipping veins predominate, where the cataclastic foliation dips steeply, whereas flat-lying veins or vein networks are found where the cataclastic foliation is flat-lying. Due to the lack of cross-cutting relationships, no relative chronology can be established between the two groups of veins. Conversely, within each group, cross-cutting relationships indicate that veins formed during several (i.e., at least two) seismic events.

Under the optical microscope, the light to dark brown matrix of the pseudotachylyte veins is cryptocrystalline and, in some instances, is crossed by a network of polygonal fractures reminiscent of devitrification textures (Fig. 7). Clasts are rare, well-rounded, and can show embayments. Most of them are very small ( 2 to $1 \mu \mathrm{m})$, but some can be up to $1 \mathrm{~mm}$ long. The nature of the clasts is varied: olivine, clinopyroxene and, to a lesser extent, pseudotachylyte. Acicular microlites are observed in the otherwise cryptocrystalline matrix. Like in Cima di Gratera pseudotachylyte veins, the largest (between 20 and $80 \mu \mathrm{m}$ long) and most numerous microlites consist of clinopyroxene while the smallest $(<3 \mu \mathrm{m})$ and least abundant 


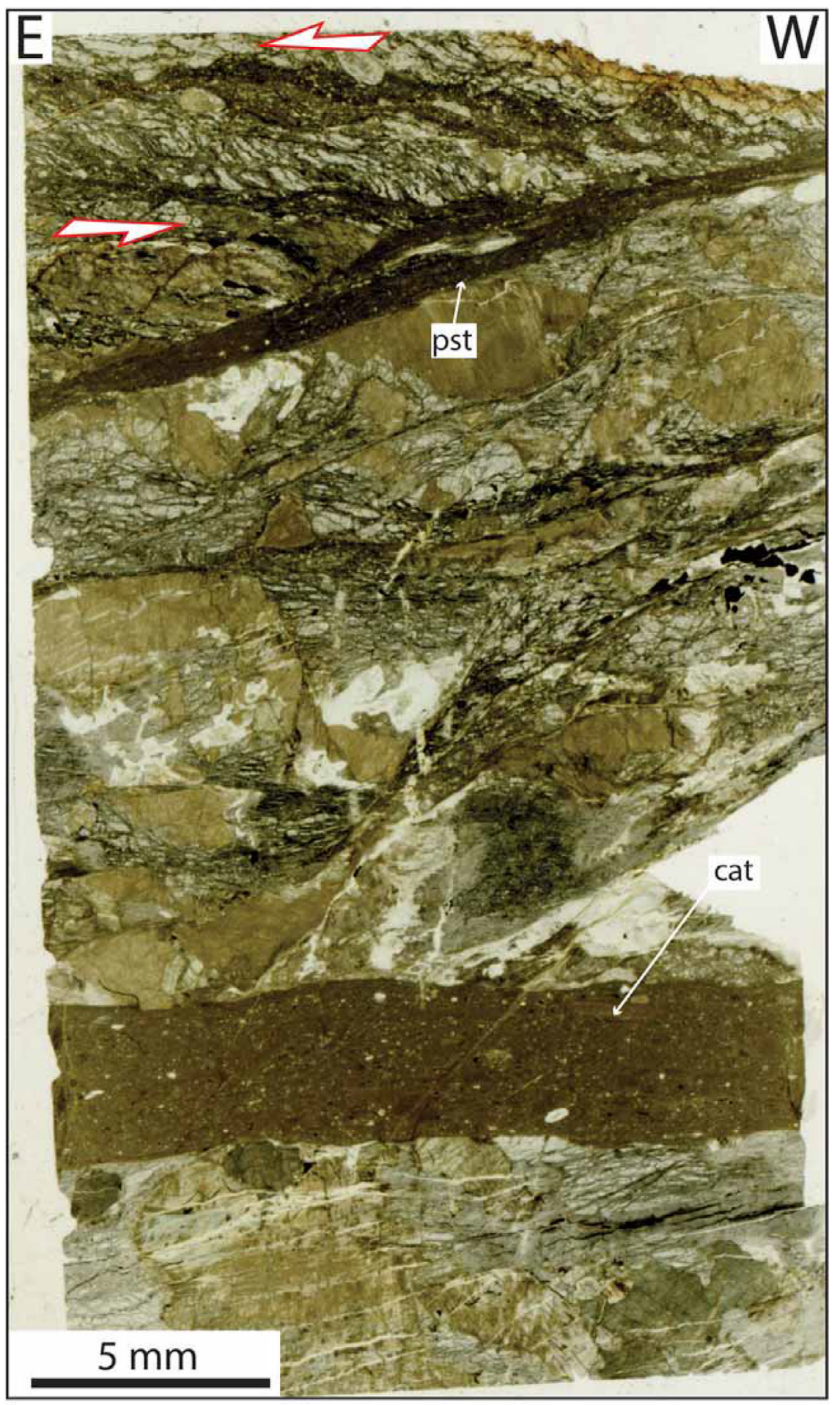

Fig. 4. Scanner image of a thin section showing a cataclastic peridotite crossed by a pseudotachylyte fault vein (pst) and by a cataclasite layer (cat) formed at the expense of a pre-existing pseudotachylyte fault vein.

consist of olivine. At variance with the Cima di Gratera occurrence, orthopyroxene microlites were not observed in the Monte Maggiore veins.

The chemical composition of pseudotachylyte matrix and microlites was investigated by microprobe (Tab. 1). Clinopyroxene microlites show augite to diopside compositions. Their
Fe content is slightly lower than in the host-rock clinopyroxenes. Minor element contents (namely $\mathrm{Cr}_{2} \mathrm{O}_{3}$ and $\mathrm{NiO}$ ) of clinopyroxene microlites are similar to those of host-rock clinopyroxenes. Because of their small size, microprobe analysis of the olivine microlites is to be taken with caution, since the matrix surrounding the microlites was likely partly 

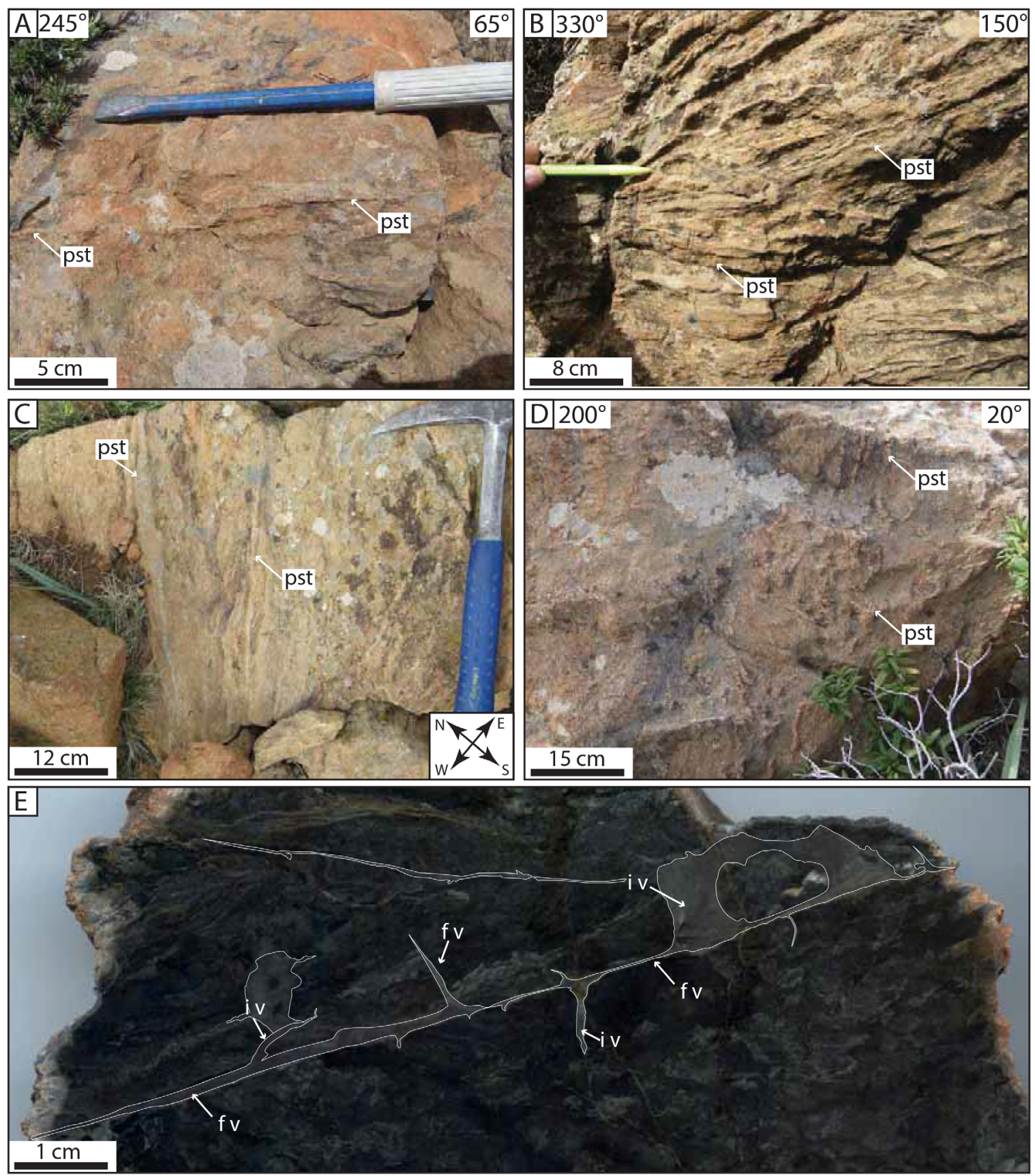

Fig. 5. Outcrop-scale aspect of pseudotachylyte (pst) fault veins crossing serpentinized peridotite (pictures A to D from locality 1, E from locality 3). A. Isolated flat-lying fault vein. B. Gently to moderately dipping network of fault veins. C. Steeply dipping fault veins (viewed from above). D. Steeply dipping fault veins (side view). E. Hand sample polished section of a serpentinized peridotite showing a fault vein (fv) and injection veins (iv).

included in the chemical analyses. Despite this limitation, analyses show that the $\mathrm{Mg}$ number of the olivine microlites (85.3) is close to that of the host peridotite olivines (84.35). The results summarized in Table 1 further permit a comparison between the chemical composition of the Maggiore pseudotachylyte and that from the Cima di Gratera (Deseta et al., 2014a, b). The above mentioned Mg number (85.3) is similar to that of the olivine microlites (84.98) of the Cima di Gratera occurrences. Concerning clinopyroxene, the $\mathrm{Ca}$ content of the Monte Maggiore microlites ( 11.73 to $24.81 \% \mathrm{CaO}$, with most values around 23\%) is higher than that of their Cima di Gratera counterpart (about $11 \% \mathrm{CaO}$ ). Conversely, the $\mathrm{Mg}$ content of the Cima di Gratera microlites (27.37 to $31.67 \% \mathrm{Mg} 0$ ) is higher than that of their Monte Maggiore counterparts (17.35 to $26.97 \%$, with most values around $18 \%$ ). The same observation holds for $\mathrm{Al}$ content (2.36 to $6.5 \% \mathrm{Al}_{2} \mathrm{O}_{3}$ at Cima di Gratera vs. 0.93 to $3.5 \%$ at Monte Maggiore). For both occurrences, the $\mathrm{FeO}$ content is quite varied, but the values remain similar (3.36 to $8.5 \% \mathrm{FeO}$ for Cima di Gratera, 2.32 to $7.03 \%$ for Monte Maggiore). Lastly, for the two occurrences, 


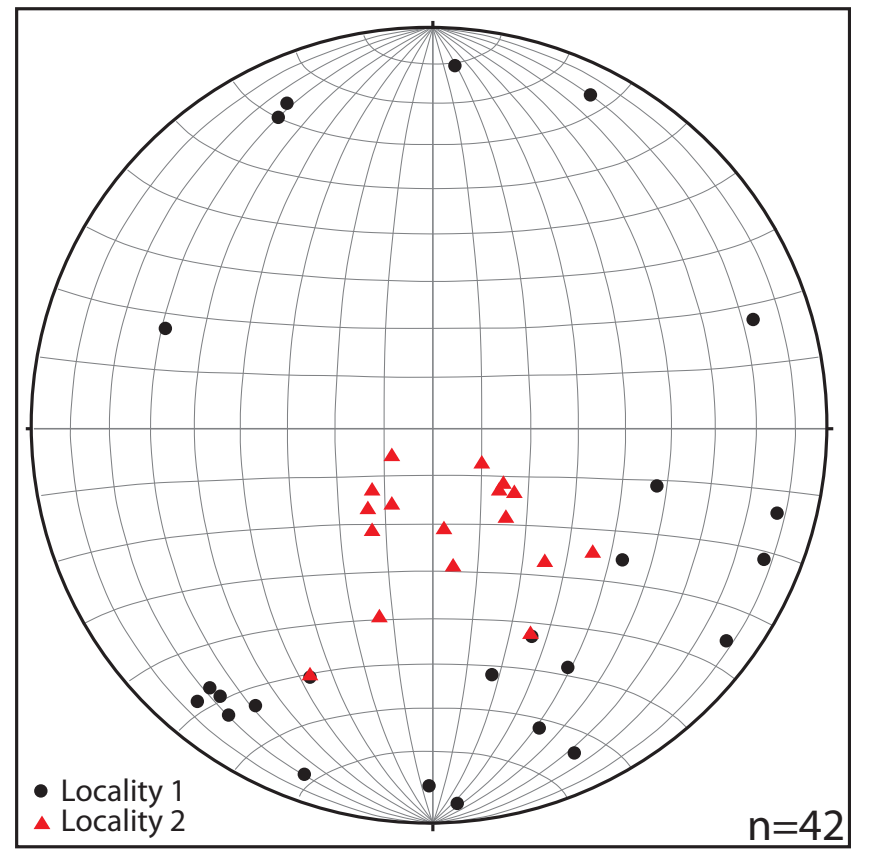

Fig. 6. Lower-hemisphere equal-area projections of poles to pseudotachylyte fault veins from localities 1 (black circles) and 2 (red triangles).

the vein matrix shows a composition close to that of olivine, with significant contents in $\mathrm{Al}_{2} \mathrm{O}_{3}$ and $\mathrm{CaO}$ likely reflecting the melting of aluminous-rich minerals in the host peridotite, namely spinel and plagioclase. Together, these analyses suggest that the chemical composition of pseudotachylyte veins from the Cima di Gratera and Monte Maggiore localities are similar.

\subsection{Ultracataclasite veins}

Ultracataclasite veins are observed at locality 1 , where the peridotite foliation is flat-lying or gently dipping. They look like the pseudotachylyte veins (same dark green color, same flat-lying attitude), but are thicker (from $5 \mathrm{~mm}$ to $2 \mathrm{~cm}$ ), do not show the glassy aspect of the pseudotachylyte and lack injection veins. They are flat-lying or gently dipping, like the cataclastic foliation of the host rock.

In thin sections (Fig. 8), ultracataclasite shows angular clasts of pyroxene, olivine, feldspar and variably serpentinized peridotite. The smallest clasts are beyond the resolution of the optical microscope, while the largest can be up to $5 \mathrm{~mm}$ long. In addition to host rock-derived clasts, fragments of pseudotachylyte are abundant. They typically display elliptical shapes whose largest dimension can reach $2 \mathrm{~mm}$. Pseudotachylyte remnants, still attached to the wall rock, are also present along the vein boundaries. These observations suggest that ultracataclasite "veins" or layers are in fact former pseudotachylyte veins that were subjected to brittle shear reactivation. The incorporation of the host serpentinized peridotite suggests that some vein thickening occurred during reactivation. Because of the lack of any indicator, the kinematics of the brittle reactivation of the pseudotachylyte fault veins cannot be determined. No cataclastic reactivation could be observed along steeply dipping pseudotachylyte veins.

\section{Discussion}

\subsection{Depth of formation of the Monte Maggiore pseudotachylytes}

Like the Cima di Gratera occurrences, the Monte Maggiore peridotite-hosted pseudotachylyte veins lack mineral assemblages that could provide an estimate of the pressure (that is, the depth) of formation. In the Cima di Gratera case, a depth estimate can be inferred from omphacite microlites in gabbrohosted veins, which were most likely formed contemporaneously with the peridotite-hosted veins. The preservation of omphacite indicates a pressure of $1.8-2.6 \mathrm{MPa}$, that is, a depth of formation between 60 and $90 \mathrm{~km}$ (Deseta et al., 2014a; Magott et al., 2017). In the Monte Maggiore unit, the gabbro dykes do not contain any pseudotachylyte veins. They therefore do not provide any constraint regarding the depth of fossilized seismicity. Earthquakes could have occurred at depth in the subducting slab, like for the Cima di Gratera occurrences, but also at shallow depths at the ridge during oceanic accretion. The only observations that can put some constraints on the depth of formation of the Monte Maggiore paleo-earthquakes consist in antigorite veins cross-cutting pseudotachylyte veins (Fig. 9). Since antigorite is a polymorph that forms only at high temperature, this cross-cutting relationship rules out formation of pseudotachylyte during the last stages of exhumation or after exhumation. Additional petrographical investigations are needed to specify whether the Monte Maggiore pseudotachylyte was formed at the midoceanic ridge or in the Wadati-Benioff zone of the subducting slab.

\subsection{Chronology and kinematics associated with pseudotachylyte-forming and cataclasite-forming events and comparison with observations from the Cima di Gratera pseudotachylyte}

In the Monte Maggiore klippe, pseudotachylyte fault veins are hosted in a cataclastic peridotite and are flat-lying or steeply dipping. They are parallel to a cataclastic foliation developed in the host peridotite. The steeply dipping cataclastic foliation is cross-cut by the flat-lying cataclastic foliation, showing that it is older and suggesting that steeply dipping pseudotachylyte fault veins could likewise be older that the flat-lying ones. The deflection of the steeply dipping foliation suggests that the sense of shear associated with the flat-lying cataclastic foliation is top-to-the-W. Within each of the two groups of pseudotachylyte veins (i.e., flat-lying vs. steeply dipping), cross-cutting relationships indicate that fault veins formed during several (at least two) seismic events, although the exact number of events cannot be estimated. These field observations are similar to those concerning the Cima di Gratera peridotite-hosted fault veins (Magott et al., 2016, 2017), with one difference: while at Cima di Gratera, the chronology between steeply dipping and flat-lying cataclastic foliations could not be determined, it can be ascertained in the Monte Maggiore area (Figs. 2 and 3).

Thin-section scale observations relevant to chronology and kinematics of deformation can be summarized as follows: 

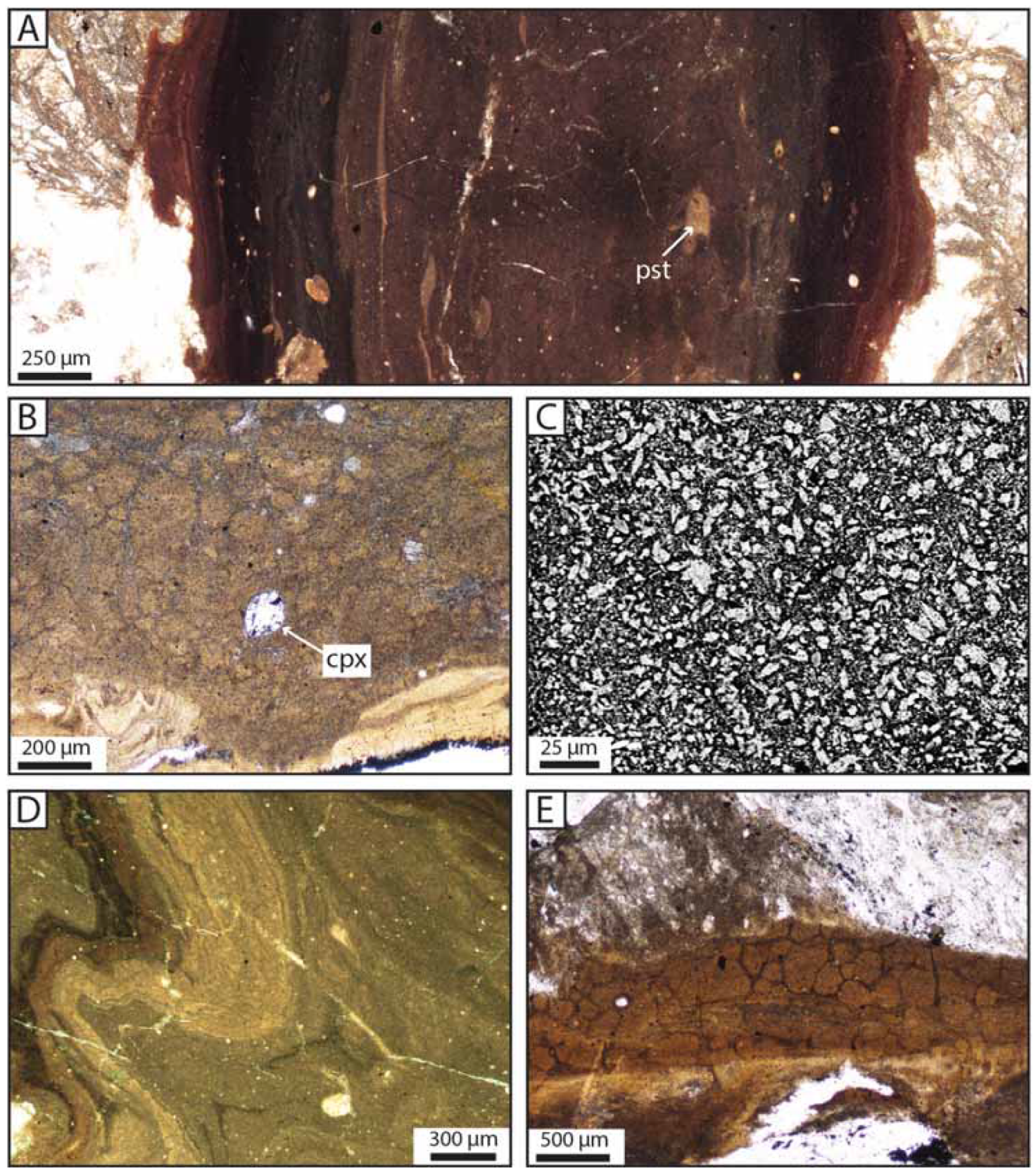

Fig. 7. Photomicrographs of pseudotachylyte veins. A. Injection vein showing zonation parallel to boundaries with flow banding (outlined by aligned clasts) and with chilled margins (locality 1). The darker outer sides correspond to chilled margins. Note the presence of pseudotachylyte clasts indicating a polyphase seismic activity. B. Well-rounded clinopyroxene clast (cpx) embedded in a fault vein (locality 1). C. Scanning electron microscope image of olivine and pyroxene microlites in a fault vein (locality 1). D. Flow fold frozen in an injection vein (locality 2 ). E. Cryptocrystalline matrix of a fault vein pseudotachylyte showing polygonal cracks interpreted as devitrification textures (locality 2 ).

- due to the lack of shear sense criteria, the kinematics of the seismic slip that led to the formation of pseudotachylyte veins remains unknown in the study area, while it is top-tothe-W in the Cima di Gratera area (Magott et al., 2016);

- some flat-lying pseudotachylyte veins were reactivated in a brittle manner and were changed into ultracataclasites. Because of the lack of formation of frictional melt associated with this late reactivation, it is not possible to determine whether the brittle event was seismic or not;
- the kinematics of the formation of the flat-lying cataclastic foliation in thin section (top-to-the-E, Fig. 4) is opposite to that deduced from outcrop-scale observations (top-to-theW, Fig. 3).

Unlike for the Cima di Gratera top-to-the-W shear sense (Magott et al., 2016), the kinematics of the seismic faulting that led to the formation of the Monte Maggiore pseudotachylyte veins is undetermined. Conversely, top-to-the-E 
Table 1. Results of microprobe analyses of Monte Maggiore pseudotachylyte veins and host peridotite.

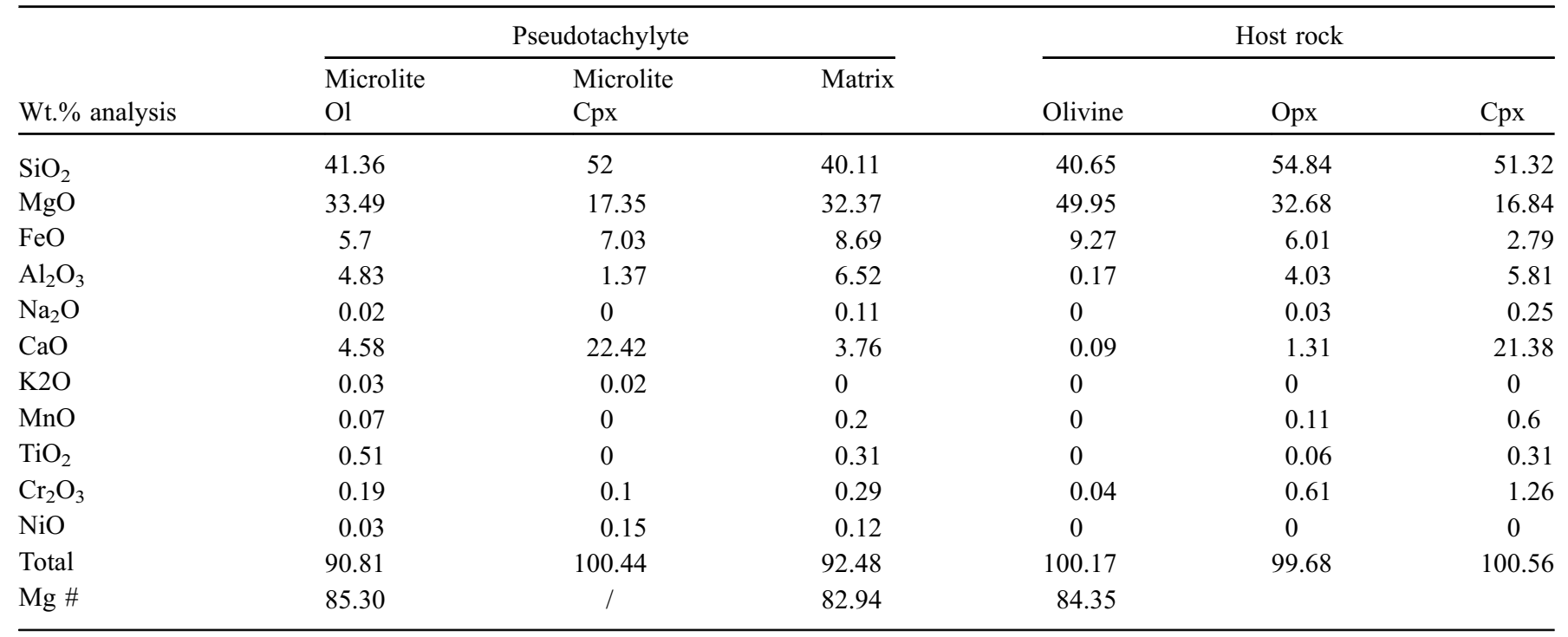
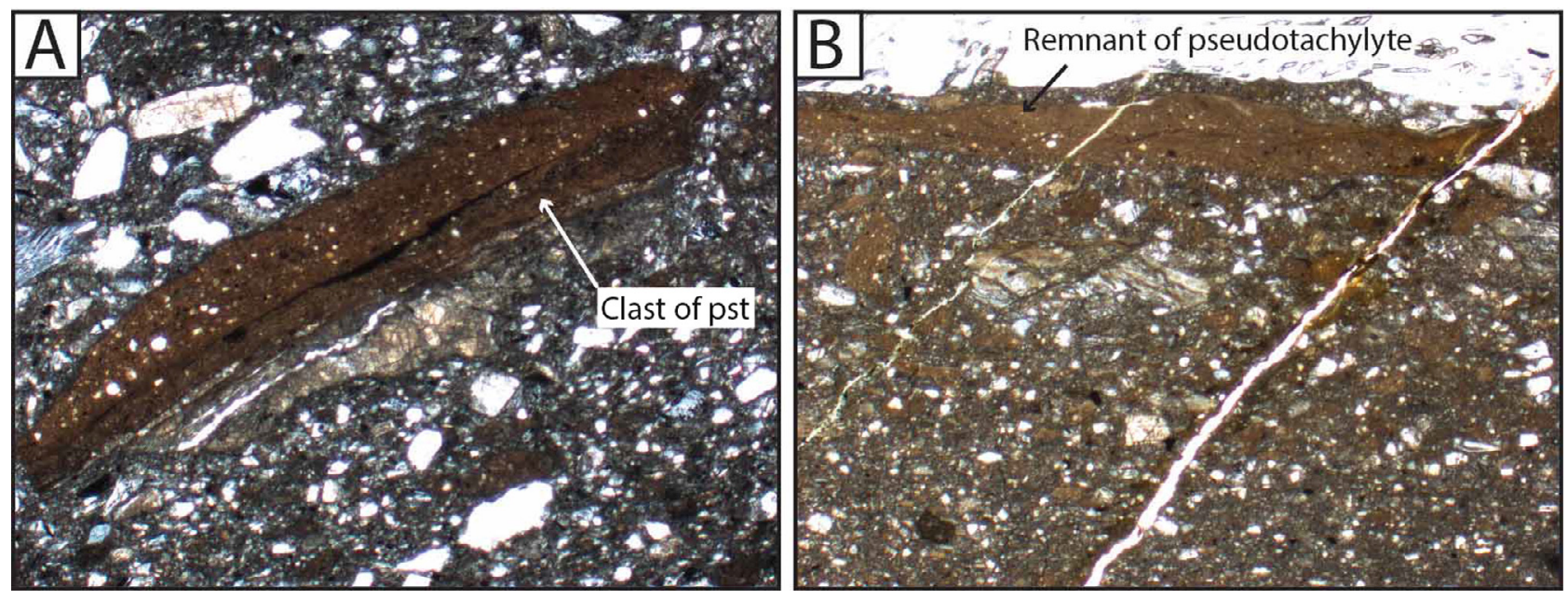

Fig. 8. Photomicrographs of cataclasite layers formed by cataclasis at the expense of pseudotachylyte veins (width of pictures is $2.5 \mathrm{~mm}$ ). A. Clast of pseudotachylyte embedded in an ultracataclastic matrix. B. Remnant of pseudotachylyte preserved along the boundary with host serpentinized peridotite.

shear senses are observed in the Monte Maggiore cataclastic reworking of the pseudotachylyte veins. Regional data (Faure and Malavieille, 1981; Mattauer et al., 1981; Fournier et al., 1991; Jolivet et al., 1991; Daniel et al., 1996) as well as observations from the Cima di Gratera (Ferré et al., 2016; Magott et al., 2017) show that:

- both top-to-the-W and top-to-the-E shear senses are preserved in ductilely deformed rocks from Alpine Corsica and;

- top-to-the-E shear deformation post-dates the top-to-the$\mathrm{W}$ one. The top-to-the-E brittle deformation preserved in the Monte Maggiore cataclastic peridotite could be related to this late deformation episode. However, the scarcity of samples on which shear sense criteria can be ascertained and the restricted spatial distribution of the deformed rocks prevents further discussion of this deformation.

\subsection{Correlation between the Cima di Gratera and the Monte Maggiore pseudotachylyte occurrences}

The Monte Maggiore pseudotachylyte occurrence is reminiscent of that from the Cima di Gratera. In the two areas, the rock hosting the veins is a cataclastic peridotite. Both steeply dipping and flat-lying (to gently dipping) veins are present. At the outcrop scale, the overall aspect of the veins is complex, due to anastomosed vein networks and to frequent offsetting of veins by minor faults. A ultracataclastic reworking of the flat-lying veins, with a top-tothe-E shear sense, is possibly preceded by a top-to-the-W cataclastic shear (foliation deflection), but relative chronology between the two events is lacking. The chemical composition of pseudotachylyte vein matrix and microlites in the Monte Maggiore area (this study) is quite similar to 

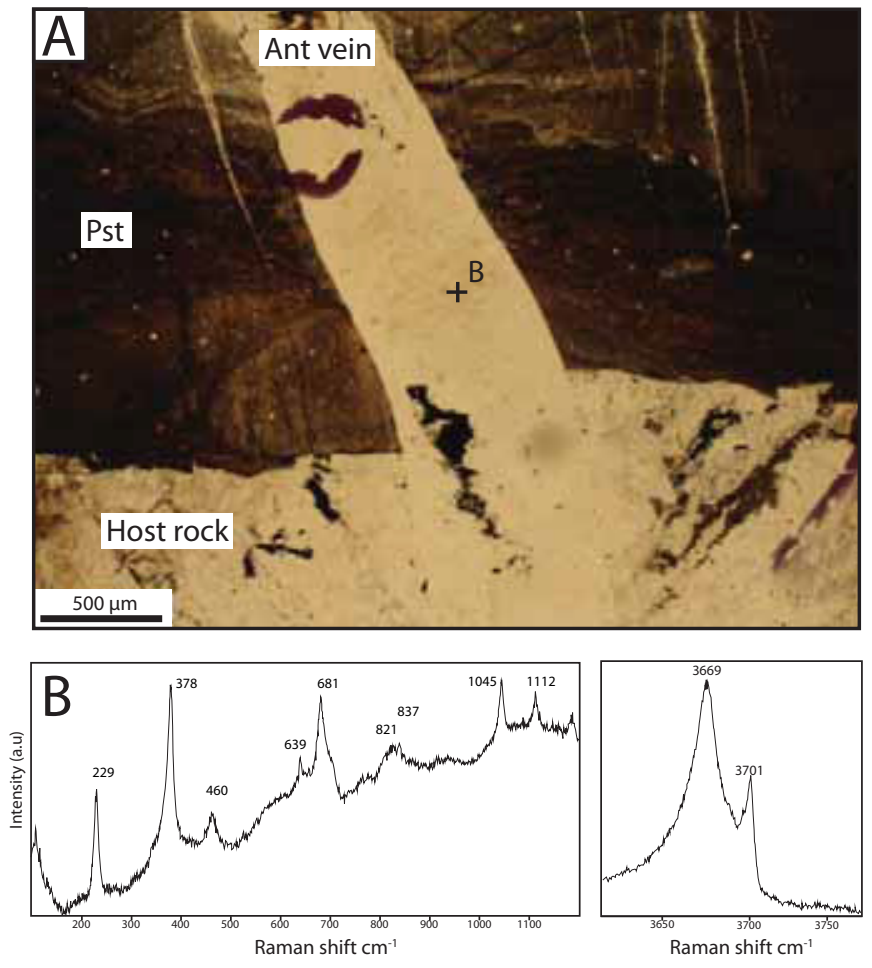

Fig. 9. Pseudotachylyte vein-antigorite vein relationship. A. Scanner image of a part of a thin section showing an antigorite vein (Ant vein) cross-cutting a pseudotachylyte fault vein (Pst). Also indicated is the point $(+\mathrm{B})$ where the Raman analysis was done. B. Results of Raman micro-spectroscopy with antigorite characteristic spectral signatures.

that of their counterparts in the Cima di Gratera area (Deseta et al., 2014a, b).

Further comparison between the two areas is hindered by the limited size of exposures in the Monte Maggiore area and by the uncertainty, in this last area, regarding the setting (midoceanic ridge or subducting slab) of earthquake hypocenters. Despite these two limits, it is however plausible that the Monte Maggiore occurrence could be the lateral equivalent of the lowest part of the pseudotachylyte-bearing ultramafic unit at the Cima di Gratera (Fig. 10), the possibly above-lying pseudotachylyte-bearing mafic rocks, if ever present, having been eroded. More specifically, in their study of the Cima di Gratera unit, Andersen et al. (2014) report an $80 \mathrm{~cm}$ thick pseudotachylyte vein and suggest that this vein is the result of a magnitude 7 or 8 event. The area of the rupture surface of such a large event is typically several hundreds to several thousands of square kilometers. Hence, the lateral extension (length) of such a rupture surface is between several tens and a few hundreds of kilometers (Strasser et al., 2010). The scars of such a large event, whatever the main rupture surface or the (numerous) small surfaces corresponding to the aftershocks, should logically be traced over large distances. It is not unrealistic to consider that the small veins exposed in the Monte Maggiore unit are aftershocks of one or several large ruptures exposed in the Cima di Gratera unit. At a more regional scale, lateral equivalents of this fossil seismic zone should be looked for further south in Corsica as well as further north in the Western Alps.

\subsection{Reconstruction of the subduction zone at the epoch of formation of the pseudotachylytes}

Figures 11 and 12 depict a possible paleogeographic setting of the subduction zone in the vicinity of Corsica at the time of formation of the Monte Maggiore pseudotachylyte veins. This reconstruction is based on the following assumptions:

- the Monte Maggiore pseudotachylyte veins were not formed at the mid-oceanic ridge or at shallow depths in the trench, but in the subducting slab at intermediate depths (>60 km depth), following the same scenario as the one proposed for the Cima di Gratera occurrences (Andersen et al., 2008, 2014; Deseta et al., 2014a, b; Magott et al., 2016, 2017);

- the timing of the peak of the high-pressure metamorphism (eclogite facies conditions) and hence that of the associated subduction are Late Eocene, namely 37.5 34 Ma (VitaleBrovarone and Herwartz, 2013);

- off Corsica, in Late Eocene times, the subducting slab was dipping eastwards or southeastwards (in present-day coordinates), to account for the top-to-the- $\mathrm{W}$ or top-tothe-NW (in present-day coordinates) sense of shear associated with blueschist facies conditions ductile deformation (Mattauer et al., 1981; Magott et al., 2017), in agreement with the reconstructions of Handy et al. (2010), Molli (2008), Molli and Malavieille (2010) and Marroni et al. (2017);

- based on the paleomagnetic constraints obtained by Advokaat et al. (2014), the Corsica-Sardinia crustal block suffered from a counterclockwise rotation of $\sim 45^{\circ}$ in postearly Eocene to pre-Oligocene times $(50 \sim 30 \mathrm{Ma})$ in addition to the well-recognized counterclockwise rotation of $\sim 35^{\circ}$ in early Miocene times (21.5 16 Ma).

Since the timing of the first (oldest) rotation overlaps that of the high-pressure metamorphism, there is an uncertainty regarding the amount of correction that must be applied to get the position of the slab at the epoch of subduction. Given the fact that the proposed reconstruction is drawn for the situation $35 \mathrm{Ma}$ ago (approximate age of the peak high-pressure metamorphism) and by assuming that the rotation rate is constant with time, the amount of rotation experienced by the Corsica-Sardinia block is about $34^{\circ}$.

\section{Conclusion}

The Monte Maggiore unit, consisting in a series of klippes composed of ultramafic rocks (peridotite and serpentinite), tectonically rests upon continental crust-derived as well as oceanic crust-derived units. Its structural position as well as its petrological composition suggest that it is similar to the Cima di Gratera unit located $30 \mathrm{~km}$ further south. Pseudotachylyte veins present in the highest parts of the Monte Maggiore klippe display several similarities with veins reported from the ultramafic rocks of the Cima di Gratera unit in the southern part of the Cap Corse peninsula:

- the peridotite hosting the pseudotachylyte veins is cataclastic; 


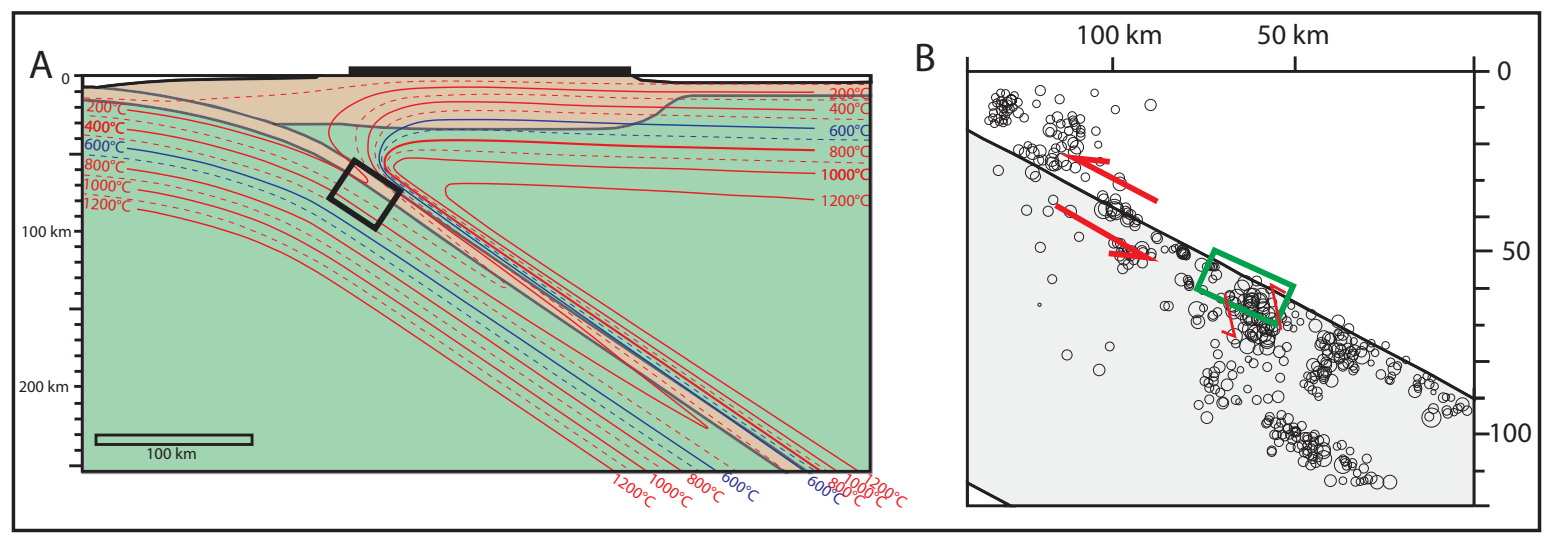

Fig. 10. Projection of the Monte Maggiore unit in the Wadati-Benioff seismic zone of a cold subduction setting such as the Pacific plate subducting beneath NE Japan. A. General setting (isotherms after Hacker et al. [2003] and Peacock [2001]). B. Detailed setting. The rectangle stands for the location of the Cima di Gratera and Monte Maggiore pseudotachylyte occurrences. Hypocenters (background circles) and kinematics (red arrows) of the 2002-2003 seismic activity in the uppermost part of the Pacific plate off NE Japan (Hasegawa et al., 2007) are given for comparison (see Magott et al. [2016] for further details).

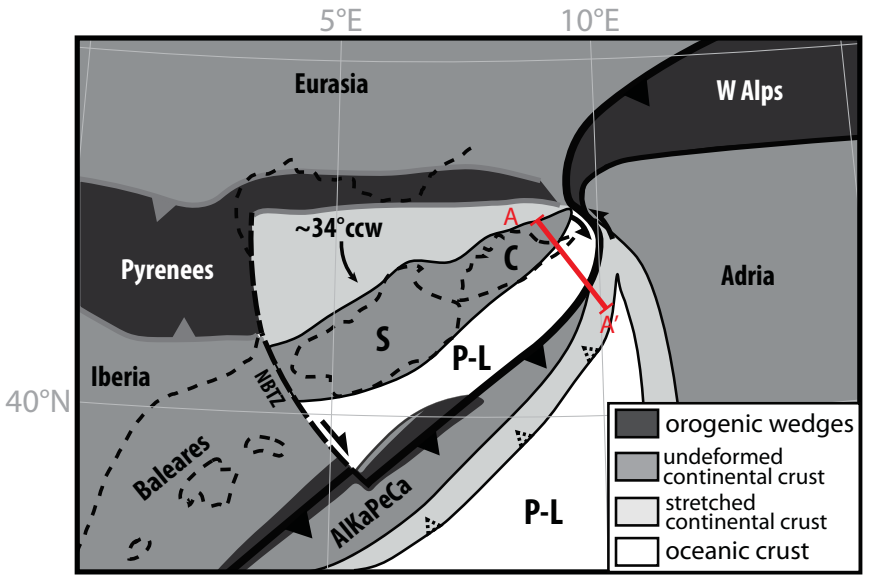

Fig. 11. Possible paleogeographic setting of the Alpine-Corsican subduction zone in Late Eocene times (35 Ma ago), based on Advokaat et al. (2014), Handy et al. (2010), Marroni et al. (2017), Molli (2008), Molli and Malavieille (2010), Turco et al. (2012), Van Hinsbergen et al. (2014) and Vignaroli et al. (2008). AlKaPeCa is a hypothetical micro-continent now dismembered in the Alboran, Kabylian, Peloritan and Calabrian areas (Bouillin et al., 1986). C: Corsica; P-L: Piemonte-Ligurian oceanic basin; NBTZ: North Balearic transform zone; S: Sardinia. Solid triangles delineate the Corsican subduction zone. Dashed triangles along the southern margin of $\mathrm{AlKaPeCa}$ delineate the location of the future (Oligocene) "Apennine" subduction. $34^{\circ} \mathrm{ccw}$ stands for a counter-clockwise rotation of $34^{\circ}$. A-A' is the cross-section of Figure 12.

- both steeply dipping and flat-lying veins are exposed, although no relative chronology can be determined at Cima di Gratera;

- the large number of veins cross-cutting each other indicates a large number of seismic events. Moreover, the small lateral extension and the small thickness of fault veins suggest that the pseudotachylyte most likely results from numerous small magnitude seismic events such as swarms or aftershocks rather than from large magnitude shocks.

Conversely, the following points are at variance with what is observed at the Cima di Gratera area:

- due to the lack of high-pressure mineral assemblages in Monte Maggiore gabbros, an ambiguity regarding the depth and therefore the setting of pseudotachylyte formation remains there: Were veins formed at or near the mid-oceanic ridge or at depth along the Wadati-Benioff zone of the subducting Piemonte-Ligurian oceanic lithosphere?

- co-seismic (i.e., pseudotachylyte-associated) top-to-the-W sense of shear is ascertained at Cima di Gratera but not at Monte Maggiore;

- subsequent cataclastic reworking of pseudotachylyte is observed at Monte Maggiore but not at Cima di Gratera.

Despite these differences or uncertainties, the two pseudotachylyte occurrences hosted in mafic or ultramafic rocks from similar ophiolitic units in Cape Corse are possibly lateral equivalents. If so, they may represent the remnants of a dismembered Wadati-Benioff seismic zone, which was formed during the Late Cretaceous to Paleogene subduction of the Ligurian Tethys oceanic lithosphere.

Acknowledgements. This work was funded by the CNRSINSU TelluS-ALEAS program. Electronic microscopy was supported by the RENATECH Network. The manuscript benefited from constructive comments from T.B. Andersen and an anonymous reviewer. 


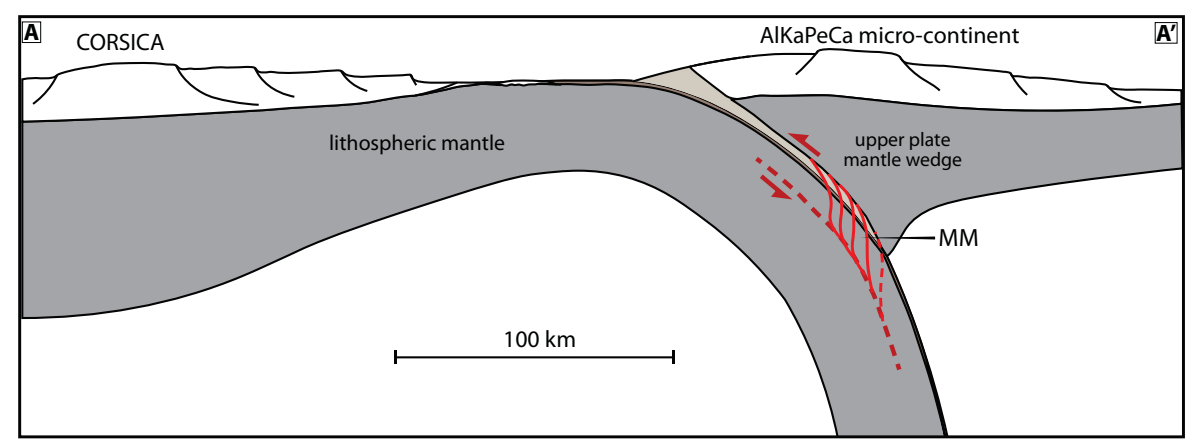

Fig. 12. Schematic cross-section A-A' showing the subduction of the Piemonte-Ligurian oceanic lithosphere beneath AlKaPeCa microcontinent along with the tectonic incorporation of parts of the subducting slab to the base of the upper plate. MM: future Monte Maggiore tectonic unit. No vertical exaggeration.

\section{References}

Abers GA, Nakajima J, van Keken PE, Kita S, Hacker BR. 2013. Thermal-petrological controls on the location of earthquakes within subducting plates. Earth and Planetary Science Letters 369: 178-187.

Advokaat EL, van Hinsbergen DJ, Maffione M, Langereis CG, Vissers RL, Cherchi A, et al. 2014. Eocene rotation of Sardinia, and the paleogeography of the western Mediterranean region. Earth and Planetary Science Letters 401: 183-195. Doi: 10.1016/j. eps1.2014.06.012.

Agard P, Vitale-Brovarone A. 2013. Thermal regime of continental subduction: the record from exhumed HP-LT terranes (New Caledonia, Oman, Corsica). Tectonophysics 601: 206-215.

Andersen TB, Austrheim H. 2006. Fossil earthquakes recorded by pseudotachylytes in mantle peridotite from the Alpine subduction complex of Corsica. Earth and Planetary Science Letters 242: 58-72.

Andersen TB, Mair K, Austrheim H, Podladchikov YY, Vrijmoed JC. 2008. Stress release in exhumed intermediate and deep earthquakes determined from ultramafic pseudotachylyte. Geology 36: 995-998.

Andersen TB, Austrheim H, Deseta N, Silkoset P, Ashwal LD. 2014. Large subduction earthquakes along the fossil Moho in Alpine Corsica. Geology 42: 395-398.

Angiboust S, Agard P, Yamato P, Raimbourg H. 2012. Eclogite breccias in a subducted eclogite: A record of intermediate-depth earthquake? Geology 40: 707-710.

Austrheim H, Andersen TB. 2004. Pseudotachylytes from Corsica: Fossil earthquakes from subduction complex. Terra Nova 16: 193197. Doi: 10.1111/j.1365-3121.2004.00551.x.

Beccaluva L, Chiesa S, Delaloye M. 1981. K/Ar age determinations on some Tethyan ophiolites. Rendiconti della Societa Italiana di Mineralogia e Petrologia 37: 869-880.

Bouillin, JP, Durand-Delga M, Olivier P. 1986. Betic-Rifian and Tyrrhenian arcs: distinctive features, genesis and development stages. In Developments in Geotectonics 21: 281-304.

Braeck S, Podladchikov YY. 2007. Spontaneous thermal runaway as an ultimate failure mechanism of materials. Physical Review Letters 98: 095504.

Brudzinski MR, Thurber CH, Hacker BR, Engdahl ER. 2007. Global prevalence of double Benioff zones. Science 316: 1472-1474.

Daniel JM, Jolivet L, Goffé B, Poinssot C. 1996. Crustal-scale strain partitioning: footwall deformation below the Alpine OligoMiocene detachment of Corsica. Journal of Structural Geology 18: $41-59$.
Debret B. 2013. Serpentinites, vecteurs des circulations fluides et des transferts chimiques de l'océanisation à la subduction: exemple dans les Alpes occidentales. Thèse Université Blaise PascalClermont-Ferrand II.

Deseta N, Andersen TB, Ashwal LD. 2014a. A weakening mechanism for intermediate-depth seismicity? Detailed petrographic and microtextural observations from blueschist facies pseudotachylytes, Cape Corse, Corsica. Tectonophysics 610: 138-149.

Deseta N, Ashwal LD, Andersen TB. 2014b. Initiating intermediatedepth earthquakes: Insights from a HP-LT ophiolite from Corsica. Lithos 206-207: 127-146.

Durand-Delga M. 1984. Principaux traits de la Corse alpine et corrélations avec les Alpes ligures. Mémoires de la Société Géologique d'Italie 28: 285-329.

Durand-Delga M, Rossi P. 2002. About the Ligurian-Piedmontese Jurassic Ocean on the transect Corsica-Apennines. Comptes Rendus Géoscience 334: 227-228.

Faure M, Malavieille J. 1981. Étude structurale d'un cisaillement ductile: le charriage ophiolitique corse dans la région de Bastia. Bulletin de la société géologique de France 23: 335-343.

Ferré EC, Chou YM, Kuo RL, Yeh EC, Leibovitz NR, Meado AL, et al. 2016. Deciphering viscous flow of frictional melts with the mini-AMS method. Journal of Structural Geology 90: 15-26 Doi: 10.1016/j.jsg.2016.07.002.

Fournier M, Jolivet L, Goffé B, Dubois R. 1991. Alpine Corsica Metamorphic Core Complex. Tectonics 10: 1173-1186.

Frohlich C. 2006. Deep Earthquakes. Cambridge: Cambridge University Press, 573 p.

Hacker BR, Peacock SM, Abers GA, Holloway SD. 2003. Subduction factory 2 . Are intermediate-depth earthquakes in subducting slabs linked to metamorphic dehydration reactions? Journal of Geophysical Research 108: 2030. Doi: 10.1029/2001JB001129.

Handy MR, Schmid SM, Bousquet R, Kissling E, Bernoulli D. 2010. Reconciling plate-tectonic reconstructions of Alpine Tethys with the geological-geophysical record of spreading and subduction in the Alps. Earth-Science Reviews 102: 121-158.

Harris L. 1985. Progressive and polyphase deformation of the Schistes Lustrés in Cap Corse, Alpine Corsica. Journal of Structural Geology 7: 637-650.

Hasegawa A, Uchida N, Igarashi T, Matsuzawa T, Okada T, Miura S, Suwa Y. 2007. Asperities and quasi-static slips on the subducting plate boundary east off Tohoku, northeastern Japan. In: Dixon TH, Moore JC, eds. The seismogenic zone of subduction thrust Faults. New York: Columbia University Press, pp. 451-475.

Houston H. 2015. Deep Earthquakes. In: Schubert G, ed. Treatise on geophysics, 2nd ed. Vol. 4. Oxford: Elsevier, pp. 329-354. 
Igarashi T, Matsuzawa T, Umino N, Hasegawa A. 2001. Spatial distribution of focal mechanisms for interplate and intraplate earthquakes associated with the subducting Pacific plate beneath the northeastern Japan arc: a triple-planed deep seismic zone. Journal of Geophysical Research 106: 2177-2191.

Jackson MD, Ohnenstetter M. 1981. Peridotite and gabbroic structures in the Monte Maggiore massif, Alpine Corsica. The Journal of Geology 89: 703-719.

Jiao W, Silver PG, Fei Y, Prewitt CT. 2000. Do intermediate- and deep-focus earthquakes occur on preexisting weak zones? An examination of the Tonga subduction zone. Journal of Geophysical Research 105: 28125-28138.

John T, Medvedev S, Rüpke LH, Andersen TB, Podladchikov YY, Austrheim H. 2009. Generation of intermediate-depth earthquakes by self-localizing thermal runaway. Nature Geoscience 2: 137-140, Doi: 10.1038/NGEO419.

Jolivet L, Dubois R, Fournier M, Goffé B, Michard A, Jourdan C. 1990. Ductile extension in Alpine Corsica. Geology 18: 10071010.

Jolivet L, Daniel JM, Fournier M. 1991. Geometry and kinematics of extension in Alpine Corsica. Earth and Planetary Science Letters 104: 278-291.

Jolivet L, Faccenna C, Goffé B, Mattei M, Rossetti F, Brunet C, et al. 1998. Mid-crustal shear zones in post-orogenic extension: examples from the northern Tyrrhenian Sea case. Journal of Geophysical Research 103: 12123-12160.

Kelemen P, Hirth G. 2007. A periodic shear-heating mechanism for intermediate-depth earthquake in the mantle. Nature 446: 787-790, Doi: $10.1038 /$ nature 05717 .

Kita S, Okada T, Nakajima J, Matsuzawa T, Hasegawa A. 2006. Existence of a seismic belt in the upper plane of the double seismic zone extending in the along-arc direction at depths of $70-100 \mathrm{~km}$ beneath NE Japan. Geophysical Research Letters 33: L24310. Doi: $10.1029 / 2006$ GL028239.

Lacombe O, Jolivet L. 2005. Structural and kinematic relationships between Corsica and the Pyrenees-Provence domain at the time of the Pyrenean orogeny. Tectonics 24, TC1003. Doi: 10.1029/ 2004TC001673.

Lagabrielle Y, Lemoine M. 1997. Alpine, Corsican and Apennine ophiolites: The slow-spreading ridge model. Comptes Rendus de l'Académie des Sciences 325: 909-920.

Lagabrielle Y, Vitale-Brovarone A, Ildefonse B. 2015. Fossil oceanic core complexes recognized in the blueschist metaophiolites of Western Alps and Corsica. Earth-Science Reviews 141: 1-26. Doi: 10.1016/j.earscirev.2014.11.004.

Lahondère D. 1988. Le métamorphisme éclogitique dans les orthogneiss et les métabasites ophiolitiques de la région de Farinole (Corse). Bulletin de la société géologique de France 8: 579-585.

Lahondère JC. 1992. Carte géologique de la France au 1/50000. Feuille de Luri. BRGM.

Lahondère JC, Lahondère D. 1988. Organisation structurale des « schistes lustrés » du Cap Corse (Haute-Corse). Comptes rendus de l'académie des sciences 307: 1081-1086.

Lahondère JC, Lahondère D. 1992. Notice de la carte géologique de Luri, $51 \mathrm{p}$

Li XH, Faure M, Rossi P, Lahondère D. 2015. Age of Alpine Corsica ophiolites revisited: insights from in situ zircon $\mathrm{U}-\mathrm{Pb}$ age and $\mathrm{O}-\mathrm{Hf}$ isotopes. Lithos 220-223: 179-190. Doi: 10.1016/j.lith os.2015.02.006.

Magott R. 2016. Propagation de la rupture sismique dans la lithosphère océanique: une étude basée sur l'analyse structurale des cataclasites et pseudotachylytes jalonnant les failles dans les roches mafiques et ultramafiques accrétées ou obductées sur les continents: l'exemple corse. Thèse de l'Université de FrancheComté : 278 p.

Magott R, Fabbri O, Fournier M. 2016. Subduction zone intermediate-depth seismicity: insights from the structural analysis of Alpine high-pressure ophiolite-hosted pseudotachylyte (Corsica, France). Journal of Structural Geology 87: 95-114. Doi: 10.1016/j. jsg.2016.04.002.

Magott R, Fabbri O, Fournier M. 2017. Polyphase ductile/brittle deformation along a major tectonic boundary in an ophiolitic nappe, Alpine Corsica: Insights on subduction zone intermediatedepth seismicity. Journal of Structural Geology 94: 240-257. Doi: 10.1016/j.jsg.2016.12.002.

Malavieille J. 1983. Étude tectonique et microtectonique de la nappe de socle de Centuri (zone des schistes lustrés de Corse). Conséquences pour la géométrie de la chaîne alpine. Bulletin de la société géologique de France 25: 195-204.

Marroni M, Meneghini F, Pandolfi L. 2017. A revised subduction inception model to explain the Late Cretaceous, double-vergent orogen in the precollisional western Tethys: evidence from the Northern Apennines. Tectonics 36: 2227-2249, Doi: 10.1002/ 2017 TC004627.

Mattauer M, Proust F. 1976. La Corse alpine: un modèle de genèse du métamorphisme haute pression par subduction de croûte continentale sous du matériel océanique. Comptes Rendus de l'Académie des Sciences 282: 1249-1252.

Mattauer M, Proust F, Etchecopar A. 1977. Linéation "a" et mécanisme de cisaillement simple liés au chevauchement de la nappe des schistes lustrés en Corse. Bulletin de la société géologique de France 29: 841-847.

Mattauer M, Faure M, Malavieille J. 1981. Transverse lineation and large-scale structures related to Alpine obduction in Corsica. Journal of Structural Geology 3: 401-409.

Menant A, Angiboust S, Monié P, Oncken O, Guigner JM. 2018. Brittle deformation during Alpine basal accretion and the origin of seismicity nests above the subduction interface. Earth and Planetary Science Letters 487: 84-93.

Meresse F, Lagabrielle Y, Malavielle J, Ildefonse B. 2012. A fossil ocean-continent transition of the Mesozoic Tethys preserved in the Schistes Lustrés nappe of northern Corsica. Tectonophysics 579: 4-16.

Molli G. 2008. Northern Apennine-Corsica orogenic system: an updated overview. In: Siegesmund S, Fügenschuh B, Froitzheim $\mathrm{N}$, eds. Tectonic Aspect of the Alpine-Dinaride-Carpathian System, Geological Society of London, Special Publication 298, pp 413-442.

Molli G, Malavieille J. 2010. Orogenic process and the Corsica/ Apennine geodynamic evolution: Insight from Taiwan. International Journal of Earth Sciences 100: 1207-1224. Doi: 10.1007/ s00531-010-0598-y.

Nakajima J, Uchida N, Shiina T, Hasegawa A, Hacker, BR, Kirby SH. 2013. Intermediate-depth earthquakes facilitated by eclogitizationrelated stresses. Geology 41: 659-662. Doi: 10.1130/G33796.1.

Ohnenstetter D, Ohnenstetter M, Rocci G. 1976. Etude des métamorphismes successifs des cumulats ophiolitiques de Corse. Bulletin de la société géologique de France 28: 115-134.

Ohnenstetter M, Ohnenstetter D, Vidal P, Cornichet J, Hermitte D, Mace J. 1981. Crystallization and age of zircon from Corsican ophiolitic albitites: consequences for oceanic expansion in Jurassic times. Earth and Planetary Science Letters 54: 397-408.

Peacock SM. 2001. Are the lower planes of double seismic zones caused by serpentine dehydration in subduction oceanic mantle? Geology 29: 299-302. 
Piccardo GB. 2008. The Jurassic Ligurian Tethys, a fossil ultraslowspreading ocean: the mantle perspective. Geological Society, London, Special Publications 293: 11-34.

Piccardo GB, Guarnieri L. 2010. The Monte Maggiore peridotite (Corsica, France): a case study of mantle evolution in the Ligurian Tethys. Geological Society of London Special Publications 337: 745. Doi: 10.1144/SP337.2.

Preston LA, Creager KC, Crosson RS, Brocher TM, Trehu AM. 2003. Intraslab earthquakes: Dehydration of the Cascadia Slab. Science 302: 1197-1200.

Prieto GA, Florez M, Barrett SA, Beroza GC, Pedraza P, Blanco JF, et al. 2013. Seismic evidence for thermal runaway during intermediate-depth earthquake rupture. Geophysical Research Letters 40: 6064-6068. Doi: 10.1002/2013GL058109.

Rampone E, Piccardo GB, Hofmann AW. 2008. Multi-stage melt-rock interaction in the Mt. Maggiore (Corsica, France) ophiolitic peridotites: microstructural and geochemical evidence. Contributions to Mineralogy and Petrology 156: 453-475. Doi: 10.1007/ s00410-008-0296-y.

Rampone E, Hofmann AW, Raczek I. 2009. Isotopic equilibrium between mantle peridotite and melt: Evidence from the Corsica ophiolite. Earth and Planetary Science Letters 288: 601-610. Doi: 10.1016/j.eps1.2009.10.024.

Ravna EJK, Andersen TB, Jolivet L, De Capitani C. 2010. Cold subduction and the formation of lawsonite eclogite-constraints from prograde evolution of eclogitized pillow lava from Corsica. Journal of Metamorphic Geology 28: 381-395.

Rossi P, Cocherie A, Lahondère D, Fanning N. 2002. La marge européenne de la Téthys jurassique en Corse: Datation de trondhjémites de Balagne et indices de croûte continentale sous le domaine BalagnoLigure. Comptes Rendus Géoscience 334: 313-322.

Scambelluri M, Pennacchioni G, Gilio M, Bestmann M, Plümper O, Nestola F. 2017. Fossil intermediate-depth earthquakes in subducting slabs linked to differential stress release. Nature Geoscience 10: 960-966. Doi: 10.1038/s41561-017-0010-7.

Strasser FO, Arango MC, Bommer JJ. 2010. Scaling of the source dimensions of interface and intraslab subduction-zone earthquakes with moment magnitude. Seismological Research Letters 81:941950. Doi: 10.1785/gssrl.81.6.941.

Turco E, Macchiavelli C, Mazzoli S, Schettino A, Pierantoni PP. 2012. Kinematic evolution of Alpine Corsica in the framework of Mediterranean mountain belts. Tectonophysics 579: 193-206. Doi: 10.1016/j.tecto.2012.05.010.

Van Hinsbergen DJJ, Vissers RLM, Spakman W. 2014. Origin and consequences of western Mediterranean subduction, rollback, and slab segmentation. Tectonics 33: 393-419. Doi: 10.1002/ tect.20125.

Vignaroli G, Faccenna C, Jolivet L, Piromallo C, Rossetti F. 2008. Subduction polarity reversal at the junction between the Western Alps and the Northern Apennines, Italy. Tectonophysics 450: 34-50.

Vitale-Brovarone A, Herwartz D. 2013. Timing of HP metamorphism in the Schistes Lustrés of Alpine Corsica: New Lu-Hf garnet and lawsonite ages. Lithos 172-173: 175-191.

Vitale-Brovarone A, Beltrando M, Malavielle J, Giuntoli F, Tondella E, Groppo C, et al. 2011. Inherited Ocean-Continent Transition zones in deeply subducted terranes: Insight from Alpine Corsica. Lithos 124: 273-290.

Vitale-Brovarone A, Beyssac O, Malavielle J, Molli G, Beltrando M, Compagnoni R. 2013. Stacking and metamorphism of continuous segments of subducted lithosphere in a highpressure wedge: The example of Alpine Corsica (France). Earth-Science Reviews 116: 35-56. Doi: 10.1016/j.ear scirev.2012.10.003.

Warburton J. 1986. The ophiolite-bearing Schistes Lustrés nappe in Alpine Corsica: A model for the emplacement of ophiolites that have suffered HP/LP metamorphism. In: Evans BW, Brown EH, eds, Blueschists and eclogites geological society of America Memoir 164, pp. 313-331.

Warren LM, Hughes AN, Silver PG. 2007. Earthquake mechanics and deformation in the Tonga-Kermadec subduction zone from fault plane orientations of intermediate- and deep-focus earthquakes. Journal of Geophysical Research 112: B05314. Doi: 10.1029/ 2006JB004677.

Cite this article as: Fabbri O, Magott R, Fournier M, Etienne L. 2018. Pseudotachylyte in the Monte Maggiore ophiolitic unit (Alpine Corsica): a possible lateral extension of the Cima di Gratera intermediate-depth Wadati-Benioff paleo-seismic zone, BSGF - Earth Sciences Bulletin 189: 18. 